\title{
o5. Yabancı dil olarak Türkçe öğretiminde uzaktan eğitim derslerine ilişkin deneyimler
}

\section{Mülkiye Ezgi İSKENDER ${ }^{1}$}

APA: İskender, M. E. (2021). Yabancı dil olarak Türkçe öğretiminde uzaktan eğitim derslerine ilişkin deneyimler. RumeliDE Dil ve Edebiyat Araşttrmalar Dergisi, (22), 96-117. DOI: $10.29000 /$ rumelide.885523.

\section{$\ddot{\mathbf{O} z}$}

Uzaktan eğitimin hemen bütün kademelerde yaygın bir şekilde kullanılmaya başladı̆̆ı bu son dönemde, yabancı dil olarak Türkçe öğretimi alanında yapılacak çalışmaların uzaktan eğitim süreçlerinin daha etkili bir şekilde yürütülmesi için faydalı olacağı düşünülmektedir. Bu kapsamda yapılan araştırmanın amacı, yabancı dil olarak Türkçe öğretiminde öğretim elemanlarının ve öğrencilerin uzaktan eğitimle eş zamanlı (senkron) olarak yürütülen derslere ilişkin görüşlerinin ve davranışlarının incelenmesidir. Bu çerçevede öğretim elemanlarının ve öğrencilerin sürece ilişkin görüşlerine başvurulmuş ve dersler gözlemlenmiştir. Çalışma, nitel araştırma yöntemleriyle yürütülmüştür. İç içe geçmiş tek durum deseninde düzenlenen çalışmada yarı-yapılandırılmış gözlem formu ve yarı-yapılandırılmış görüşme formu kullanılmıştır. Araştırmada 4 öğretim elemanı ve 8 öğrenci ile bire bir görüşme yapılmıştır. A2 ve B2 düzeyinde iki farklı sınıf 2 saat gözlemlenmiştir. Elde edilen verilere içerik analizi yapılmış; kod, kategori ve temalara ulaşılmıştır. Çalışma süresince yapılan gözlem ve görüşmelerden hareketle iletişimsel anlamda başarılı olan uzaktan eğitim sürecinde, mekânsal ve ekonomik avantajlar öne çıkmıştır. Buna karşılık anlatıma dayanan temel dil becerilerinden konuşma ve yazma becerilerinin geliştirilmesi süreçlerine yönelik sorunların yaşandığı, bu sorunların da uygulama imkânlarının yetersizliği ve materyal eksikliğinden kaynaklandığı ifade edilmiştir. Ayrıca gramer öğretiminden de verim alınamadığı müşahede edilmiştir. Teknik aksaklıklar, öğretim elemanlarının ve öğrencilerin çevrim içi sınıf ortamına adaptasyon sorunları da çalışma neticesinde tespit edilen olumsuz sonuçlar arasında yer almaktadır.

Anahtar kelimeler: Yabancı dil olarak Türkçe öğretimi, uzaktan eğitim, temel dil becerileri, durum çalışması, içerik analizi

\section{Experiences of distance learning courses in teaching Turkish as a foreign language}

\begin{abstract}
In this recent period, when distance education has started to be used widely at almost all levels, it is thought that the studies to be carried out in the field of teaching the Turkish language as a foreign language will be beneficial for carrying out distance education processes more effectively. The study conducted in this context aims to examine instructors and students' views and behaviours regarding the lessons conducted synchronously with distance education in teaching the Turkish language as a foreign language. In this framework, the lecturers and students' views on the process were consulted, and the courses were observed. The study was conducted with qualitative research
\end{abstract}

$1 \quad$ Arș. Gör., Atatürk Üniversitesi, Kâzım Karabekir Eğitim Fakültesi, Eğitim Bilimleri Enstitüsü, Türk Dili ve Edebiyatı Ĕgitimi ABD (Erzurum, Türkiye), ezgi.iskender@atauni.edu.tr, ORCID ID: oooo-0oo3-1673-1345 [Araştırma makalesi, Makale kayıt tarihi: 08.01.2020-kabul tarihi: 20.03.2021; DOI: 10.29000/rumelide.885523.]

\section{Adres $\mid$ Address}

RumeliDE Dil ve Edebiyat Araşttrmaları Dergisi $\quad$ RumeliDE Journal of Language and Literature Studies Osmanağa Mahallesi, Mürver Çiçeği Sokak, No:14/8 Osmanağa Mahallesi, Mürver Çiçeği Sokak, No:14/8

Kadıköy - İSTANBUL / TÜRKIYE 34714 Kadıköy - ISTANBUL / TURKEY 34714 e-posta: editor@rumelide.com

e-mail: editor@rumelide.com,

tel: +90 505 7958124, +90 2167730616 phone: +90 505 7958124, +90 2167730616 
methods. Semi-structured observation form and semi-structured interview form were used in the study, which was organized in a nested single case pattern. In the research, one-on-one interviews were conducted with 4 instructors and 8 students. Two hours of observation were made in two different classes at A2 and B2 levels. Content analysis was made on the obtained data; codes, categories and themes have been reached. Based on the observations and interviews made during the study, the spatial and economic advantages came to the fore in the process of distance education, which is successful in terms of communication. On the other hand, it was stated that there are problems related to the development of speaking and writing skills, one of the basic language skills based on expression, and these problems are caused by the inadequacy of practicing opportunities and lack of materials. It has also been observed that there is no efficiency in grammar teaching. Technical problems, adaptation problems of faculty members and students to the online classroom environment are among the negative results determined as a result of the study.

Keywords: Teaching Turkish language as a foreign language, distance education, basic language skills, case study, content analysis

\section{Giriş}

Toplum hayatını önemli ölçüde etkileyen olayların eğitim-öğretim kurumuna yansımalarının olması kaçınılmaz bir durumdur. 2019 yılının sonunda Çin'de ortaya çıkan Covid-19 salgını, yüz yüze olarak sürdürülen eğitim-öğretimin, sosyal izolasyon tedbirleri kapsamında, uzaktan eğitim yoluyla yürütülmesine neden olmuştur. Eğitim çalışmalarında firsat eşitliği ve erişilebilirlik özellikleri sayesinde son dönemlerde oldukça popüler olan uzaktan eğitim araştırmaları, salgınla birlikte yüz yüze eğitime alternatif görülen bir anlayışla yeni bir döneme girmiştir.

Keegan (1996)'a göre uzaktan eğitim, öğretici ve öğrencilerin aynı mekânda bulunmadığı/ bulunamadığı durumlarda, organizasyonlar tarafından önceden planlanıp düzenlenen teknik desteğin yardımıyla iletişimin sağlandığı öğrenmelerdir. Bu tanımdan hareketle mekândan bağımsız olma, önceden hazırlık yapma ve öğretmen-öğrenci (çift yönlü) iletişimi kavramları öne çlkmaktadır. Ancak uzaktan eğitime tarihsel bağlamda bakıldığında bu kavramın farklı anlamlarda kullanıldığı ve etkileşimin ylllar içinde değiştiği görülmektedir.

Uzaktan eğitimin kavramsal yapısının öne çıktığı dönemden sonra ilk uygulamalı başlangıç, mektupla öğretimdir. İngiltere, Fransa, ABD ve Almanya'da 19. yy'ın ilk yarısında başlayan (Al \& Madran, 2004) bu dönemde öğreticiler, mektup yoluyla öğrencilerini bilgilendirme yoluna gitmiştir (Gökmen vd. 2017). Bozkurt (2017) uzaktan eğitimin Türkiye'deki tarihsel gelişimini; kavramsal dönem (19231955), mektup dönemi [yazışarak] (1956-1975), görsel işitsel araçların kullanıldığı dönem (1976-1995) ve bilişim tabanlı dönem (1996 sonrası) olarak ayırmıştır. Mektupla uzaktan öğretimden günümüze eş zamanlı (senkron) olarak ifade edilebilecek dönem 1996 sonrasında Bilkent ve ODTÜ'nün uzaktan eğitim denemeleriyle başlamıştır. Öğrenci ve öğretmen etkileşiminin öne çıktığı günümüzdeki uzaktan eğitim anlayışının başlangıcı 1996 sonrası tarihlere dayanmaktadır.

Literatürde günümüz uzaktan eğitim anlayışının etkileriyle ilgili farklı görüşler bulunmaktadır. Eğitimin zamansal açıdan esnekliğinin olması ve ekonomik avantajları uzaktan eğitimin öne çıan olumlu özellikleri arasında sayılmaktadır. (Kandemir, 2014). Tam zamanlı çalışan ve düzenli olarak derslere katılamayan, ekonomik ve sosyal imkânları yüz yüze eğitime uygun olmayan kişiler için uzaktan eğitim, avantajlı bir yapı olarak düşünülürken (Papólas, 2013; Şen, Atasoy \& Aydın, 2010)

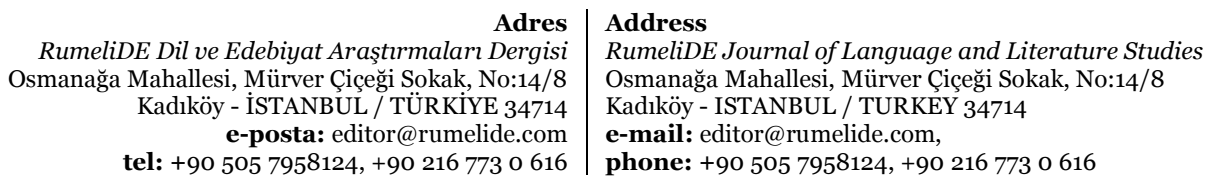


mekânsal ve zamansal açıdan sağlanan avantajların kaliteli eğitimin özünü tehdit ettiği de iddia edilmektedir (Larreamendy-Joerns \& Leinhardt 2006). Kaliteli eğitimin özünü tehdit eden dezavantajlı durumların tespit edilmesi ve iyileştirmelerin yapılması, uzaktan eğitim derslerinin başarısı üzerinde etken olan değişkenlerin incelenmesiyle bertaraf edilebilir. Genelde uzaktan eğitimin, özelde ise öğretim verilen alanların öğrenci ve öğretici merkeze alınarak incelenmesi, sürece en çok maruz kalanların temelinde bir bakış açısı sağlar ve dezavantajlı durumların tespit edilmesi için zemin hazırlar.

Uzaktan eğitimin uygulama alanları, okul öncesinden yükseköğretime kadar yürütülen örgün ve yaygın eğitimdeki bütün süreçleri kapsamaktadır. Bu bağlamda yükseköğretim kurumlarına bağlı Türkçe öğretim merkezlerindeki yabancı dil olarak Türkçe dersleri de uzaktan eğitimle yürütülmektedir. Diller İçin Avrupa Ortak Başvuru Metnine göre yabancı dil öğretiminde anlama becerisine yönelik olarak okuma ve dinleme, anlatma becerisine yönelik olarak ise konuşma ve yazma olmak üzere dört temel dil becerisi kazanımları mevcuttur (URL 1). Bu alanda derslerin içeriklerine ve hedeflerine göre uzaktan eğitimin işleyişiyle ilgili bağlamsal farklılıklar, avantajlar ve dezavantajlar bulunmaktadır. Çünkü uzaktan eğitimle yabancı dil öğretiminin kendine özgü öğretim yöntemleri bulunmaktadır. (Adıyaman, 2001). Bu bağlamda yabancı dil olarak Türkçe öğretimi özelinde uzaktan eğitimle yapılan derslerin incelenmesi, süreçte yaşanan sorunların giderilmesine katkı sunabilir.

\section{Literatür derleme}

Literatürde uzaktan eğitimin geleneksel eğitimle farklı değişkenler açısından karşılaştırıldığı çalışmalar bulunmaktadır. Öğrenci başarısı üzerine yapılan çalışmalarda iki ortamda yürütülen eğitimler arasında fark olmadığı (İbicioğlu \& Antalyalı 2005), geleneksel eğitimin uzaktan eğitimden daha başarılı olduğu (O’Malley, \& McCraw, 1999; Yiğit, Aruğaslan Özaydın, Tonguç, Özkanan, 2012) ve bunun aksine uzaktan eğitimle öğretim sürecini devam ettiren öğrencilerin daha başarılı olduğu (Balaman, 2018; Kör, Çataloğlu \& Erbay, 2013; Şahin \& Tekdal, 2005) sonuçlarını ortaya koyan araştırmalara rastlanmıştır. Bu bağlamda yapılan bütün deneysel ve meta-sentez çalışmalarının birbiriyle bağdaşmadığı görülmektedir. Uzaktan eğitimin geleneksel eğitimin yerini alıp alamayacağına dair deneysel ve karşılaştırmalı çalışmaların farklı sonuçlar sunması; uzaktan eğitim derslerinin yapısı, sürecin yürütülme şekli, öğretim elemanının ve öğrencinin teknolojik yeterlikleri gibi birçok etkenin söz konusu olabileceğine bağlanabilir.

Bilgiç ve Tüzün (2015) öğretim sürecinde uzaktan eğitimle ilgili sorumlu personel ve yöneticilerle görüşme yapmıştır. Bu görüşmeler merkez yöneticisi veya merkez yöneticisinin yönlendirmesi sonucunda seçilmiş içerik geliştirme ve sınav organizasyonu gibi konularda sorumlu personel ile gerçekleştirilmiştir. Öğretim elemanından kaynaklanan sorunlarla ilgili öne çıkan sonuçlar, teknolojik yeterliklerin sağlanamaması ve gönüllülük esasına dayalı bir ders verme durumunun olmamasından dolayı adaptasyon zorluklarının yaşanması şeklindedir. Özellikle öğretim elamanı-öğrenci etkileşimlerinde yaşanan sorunlar uzaktan eğitimin işleyişini aksatan önemli sonuçlardan bir diğeridir.

Düzakın ve Yalçınkaya (2008)'in çalışmasında öğretim elemanlarından anket formuyla alınan verilere göre; UE üzerine fakültelere dönük eğitim ihtiyacı olduğu ve yükseköğretimde UE’nin zorunluluk olarak görülmediğiyle ilgili sonuçlar elde edilmiştir. Haber ve Mills (2008) çalışmalarında öğretim elemanları ile öğrenci arasındaki etkileşim eksikliğine vurgu yapmıştır. Etkileşim ve iletişim eksikliği uzaktan eğitime ket vurabilecek bir durumdur. Gürer, Tekinarslan \& Yavuzalp (2016) 12 öğretim elemanıyla görüşme yapmış ve onların sürece yönelik görüşlerine başvurmuştur. Öğretim

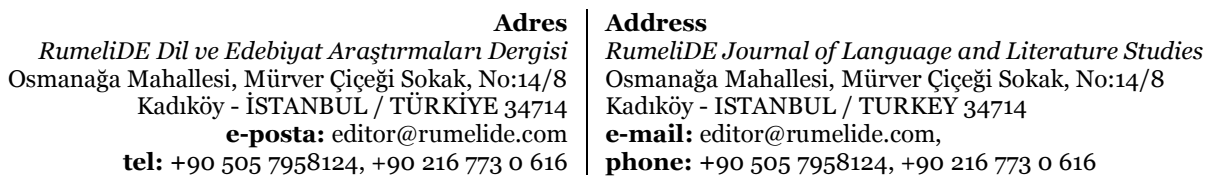


elemanlarından olumlu ve olumsuz görüşler elde edilmiş ancak sürece ilişkin gelenekselci bir tutum olduğu ve uzaktan eğitime karşı direnç gösterildiği aktarılmıştır. Semradova \& Hubackova, (2016) öğretmenlerin uzaktan eğitimle ilgili sorumluluk alma eğilimlerinin, yüz yüze eğitime nispetle daha az olduğu ancak kursun ve programın sahibi olan öğretmenlerin, uzaktan eğitime yönelik daha yüksek bir sorumluluk duygusu geliştirdiğini tespit etmiştir. Bu çerçevede uzaktan eğitim yapan öğretim elemanlarının adapte olmak konusunda zorluk yaşadığı, öğretim sürecinde yüksek sorumluluk bilincinin ve uzaktan eğitime yönelik tutumun önemi ortaya çımıştır.

Ateş ve Altun (2008)'in çalışmasında öğrencilerin uzaktan eğitime yönelik tutumları; önceden uzaktan eğitim alma durumlarına, bilgisayar kullanma deneyimlerine ve algıladıkları bilgisayar kullanma becerilerine göre anlamlı düzeyde farklılaşmaktadır. Bilgisayar bölümü öğrencilerinin hazırbulunuşluk anlamındaki birikimleri uzaktan eğitime tutumu etkilemiştir. Öğrencilerin uzaktan eğitime yönelik aşinalığının eğitim sürecine bakış açısını etkilediği görülmektedir. Bu bağlamda uzaktan eğitimle ilgili hazırbulunuşluk seviyeleri, öğretim sürecinin verimli geçmesinin bir parçasıdır. Zhao, Yan, Lai ve Tan (2005)'e göre uzaktan eğitimde program, tıpkı geleneksel eğitimdeki gibi çıtıları açısından farklılıklar göstermektedir. Öğretim programının yapısı, ders içerikleri ve değerlendirmesi bu kapsamda ele alınabilir.

Arrosagaray, González-Peiteado, Pino-Juste ve Rodrīguez-López (2019) çalışmalarında yüz yüze, harmanlanmış ve uzaktan eğitimle dil öğretimi yapılan sınıfları karşılaştırmıştır. Araştırma sonucunda bilgisayar kullanımında hazırbulunuşlukla ilgili harmanlanmış ve uzaktan eğitim modellerini kullanan öğrencilerin lehine sonuçlar elde edilmiştir. Uzaktan eğitimin teknolojik yeterliklere katkı sunması ve deneyimlerin sürece etkileri, uzaktan eğitimin öğrencilere sunduğu katkılar bağlamında değerlendirilebilir. Zhang (2018) Çin'de İngilizce eğitimi veren öğretmenler için İngilizce okuryazarlık bağlamında hizmet içi programın etkilerini araştırmıştır. SFL tabanlı öğretim kapsamında katılım açısından pratik ve esnek bir program düzenlenmiştir. Öğretmen eğitimi bağlamında araştırmanın faydaları ifade edilmiştir. Fransızca eğitimi için tasarlanmış uzaktan eğitim sonucunda özellikle esnek olmayan programları olan, tam zamanlı çalışan ve düzenli olarak programlanan derslere katılamayan öğrenciler için uzaktan eğitimin uygunluğu vurgulanmıştır (Papalas, 2013). Ekmekçi (2015), uzaktan eğitimle ilgili memnuniyet düzeylerini İngilizce dersi kapsamında incelemiştir. Öğrenci memnuniyetleri; içerik, format, okuma ve dilbilgisi açısından olumlu ancak dinleme, konuşma ve yazma dersleri açısından olumsuz seyretmiştir. Öğretmen merkezlilik öne çıkmıştır. Etkileşim seviyesine ihtiyaç arttıkça memnuniyet düşmüştür. Dil eğitiminde uzaktan eğitim sayesinde sağlanan pratiklik öne çıkmaktadır. Öte yandan eğitimde etkileşime ihtiyacın arttığı dil becerileri için düzenlemelere ihtiyaç olduğu da görülmektedir.

Yabancı dil olarak Türkçe öğretiminde yapılan çalışmalarda etkileşimsiz, asenkron uygulamalar üzerine araştırmalar öne çıkmaktadır. Videolar üzerinden yapılan uzaktan eğitimle Türkçe öğretiminin iletişimsellik anlamındaki önemi değerlendirilmiş (Pilancı, 2009), internet üzerinden uzaktan eğitim için web tabanlı asenkron uygulamalar (Şen, 2016) tespit edilmiş ve yabancı dil olarak Türkçe öğretiminde A1 düzeyinde eğitim, video ve etkinliklerinden oluşan proje çalışması (Ozan \& Göçmenler, 2018) yapılmıştır. Ancak eş zamanlı derslerle ilgili literatürde herhangi bir çalışmaya rastlanmamıştır.

Literatür taraması sonucunda ulaşılan ortak kanı, uzaktan eğitimin öğrenci ve öğretmenlere sunacağı birçok faydasının olduğu ancak sürecin geliştirmeye ve araştırılmaya ihtiyacının bulunduğudur. Uzaktan eğitimin işleyişinin farklı disiplinlerde çalışılması, süreci etkileyen faktörlerin tespit edilmesi ve iyileştirilmesi için yararlı olabilir. Çalışma bağlamında uzaktan eğitimle yabancı dil olarak

\section{Adres Address}

RumeliDE Dil ve Edebiyat Araştırmalar Dergisi $\quad$ RumeliDE Journal of Language and Literature Studies Osmanağa Mahallesi, Mürver Çiçeği Sokak, No:14/8 Osmanağa Mahallesi, Mürver Çiçeği Sokak, No:14/8 Kadıköy - ISTANBUL / TÜRKIYE 34714 Kadıköy - ISTANBUL / TURKEY 34714 e-posta: editor@rumelide.com e-mail: editor@rumelide.com, tel: +90 505 7958124, +90 2167730616 phone: +90 505 7958124, +90 2167730616 
Türkçenin farklı veri kaynaklarına başvurarak değerlendirilmesi imkânı, ayrıntılı tespitlerin yapılması ve derinlemesine bilgi edinilmesinin yolunu açacaktır.

\section{Araştırma amacı ve soruları}

$\mathrm{Bu}$ araştırmanın amacı; uzaktan eğitimle yapılan yabancı dil olarak Türkçe öğretimi derslerinin öğrenci, öğretici ve araştırmacı perspektifinde değerlendirilmesi ve konuyla ilgili mevcut deneyimlerden hareketle oluşan görüşlerin ve davranışların incelenmesidir. Bu çerçevede aşağıdaki sorulara cevap aranmıştır:

1. Uzaktan eğitimle yabancılara Türkçe öğretimine yönelik öğretim elemanlarının görüşleri nelerdir?

2. Uzaktan eğitimle yabancılara Türkçe öğretimine yönelik öğrencilerin görüşleri nelerdir?

3. Uzaktan eğitimle yabancllara Türkçe öğretimde dersler nasll yürütülmektedir?

\section{Yöntem}

$\mathrm{Bu}$ çalışma nitel araştırma yöntemi ile tasarlanmıştır. Nitel araştırmalar, yorumsamacı paradigma çerçevesinde bağlamdaki anlamı bulmayı amaçlayan araştırma yöntemidir (Meriam, 2019). Çalışmada uzaktan eğitimle yabancı dil olarak Türkçe öğretiminde öğretim elemanlarının ve öğrencilerin sürece ilişkin deneyimleri ve davranışları incelenmiştir.

Çalışmanın araştırma deseni durum çalışmasıdır. Yin (2014), desene ilişkin güncel bağlamı içinde bir durumun derinlemesine ve ayrıntılı bir şekilde araştırılması şeklinde tanımlama yapmaktadır. Uzaktan eğitimle yapılan derslerde öğreticiler ve öğrenciler yeni bir ortam ve bağlamla karşılaşmıştır. Öğretim sürecinde bu bağlam çerçevesinde yapılan dersler değerlendirilmiş; ders sürecine ilişkin görüşler ortaya çıkarılmaya çalışılmıştır.

Çoklu veri toplama tekniklerinin kullanılarak, uzaktan eğitimle yabancı dil olarak Türkçe öğretimi sürecinin ele alınması bakımından çalışmada iç içe geçmiş tek durum deseni kullanıldığı ifade edilebilir. İç içe tek durum deseni, tek bir durumun içinde birden fazla alt tabakaların mevcut olduğu zamanlarda birden fazla analiz biriminin kullanılmasıyla yürütülen çalışmalardır (Yıldırım \& Şimşek, 2018). Çalışma kapsamında uzaktan öğretim sürecinde ders ortamının öğrenci ve öğretici merkezli değerlendirilmesi ve derslerin gözlemlenmesi süreçleri işletilmiştir.

\section{Katılımcilar}

Uzaktan eğitimle yabancı dil olarak Türkçe öğretimini sürdüren öğretim elemanları ve öğrenciler araştırmanın katılımcılarını oluşturmaktadır. Katılımcıların seçimi, kolayda örnekleme yöntemine göre yapılmıştır. Kolayda örnekleme, yakın ve erişilmesi kolay olan gruptan veri toplanarak araştırmacıya hız ve pratiklik kazandırır (Yıldırım \& Şimşek, 2018). Bu çalışma Atatürk Üniversitesi Türkçe Öğretimi Uygulama ve Araştırma Merkezinde uzaktan eğitimle dersleri yürüten öğretim elemanları ve kurumda öğrenim gören öğrencilerle yapılmıştır.

Araştırmanın veri toplama süreci 3 aşamadan oluşmaktadır. Dolayısıyla 3 farklı katılımcı grubu bulunmaktadır. Öğretim elemanlarından oluşan katılımcılar, A2-B1-B2 seviyesinde ders veren 4

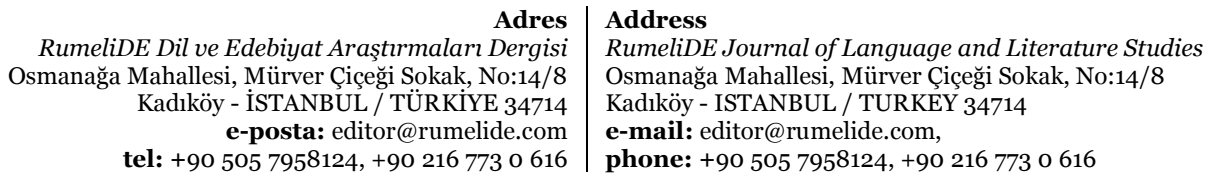


kişiden oluşmaktadır. B2 seviyesinde eğitim alan 8 öğrenci ise görüşme yapılan diğer katılımcı grubudur. Araştırmacının gözlem yapma firsatı bulduğu A2 ve B2 sınıfında toplam 38 öğrenci ve 2 öğretim elamanı da gözlemin bir parçası olarak yer almıştır. Örneklemde yer alan kişiler gönüllülük esasına göre seçilmiştir.

Tablo 1. Öğretim elemanlarılla ilgili bilgiler

\begin{tabular}{llllllll}
\hline Katılımclar & Yaş & Cinsiyet & Fakülte & $\begin{array}{l}\text { UE } \\
\text { deneyimi }\end{array}$ & $\begin{array}{l}\text { UE Program } \\
\text { bazında }\end{array}$ & $\begin{array}{l}\text { UE Yıl } \\
\text { bazında }\end{array}$ & $\begin{array}{l}\text { Eğitim } \\
\text { verdikleri } \\
\text { seviye }\end{array}$ \\
\hline ÖE1 & 35 & Kadın & Eğitim & Var & Adobe Connect & 4 & B2 \\
ÖE2 & 38 & Erkek & Edebiyat & Var & Adobe Connect & $4-5$ & B1 \\
& & & & & & & \\
ÖE3 & 40 & Kadın & Edebiyat & Yok & - & - & B2 \\
ÖE4 & 31 & Erkek & Edebiyat & Yok & - & - & A2 \\
\hline
\end{tabular}

Tablo 1'de öğretim elemanlarının demografik bilgileri ve uzaktan eğitimle ilgili deneyimlerine ilişkin bilgiler sunulmuştur. Öğretim elemanlarının uzaktan eğitime ilişkin görüşlerinin yaş, cinsiyet, eğitim durumu, fakülte, uzaktan eğitim deneyimi, program ve yl bazında uzaktan eğitim deneyimleri değerlendirilmiştir. Bulgular yorumlanırken Tablo 1'de sunulan bilgiler kullanılmıştır.

Tablo 2. Öğrencilerle ilgili bilgiler

\begin{tabular}{llllll}
\hline Katılımclar & Yaş & Cinsiyet & Uyruk & $\begin{array}{l}\text { Uzaktan Ĕgitim } \\
\text { Deneyimi }\end{array}$ & $\begin{array}{l}\text { Öğretim Teknolojilerinden } \\
\text { Faydalanma Durumu }\end{array}$ \\
\hline Ö1 & 23 & Erkek & Afganistan & Yok & Youtube \\
\hline Ö2 & 26 & Erkek & Afganistan & Yok & Youtube, Instagram \\
\hline$\ddot{O ̈}_{3}$ & 20 & Erkek & Gürcistan & Yok & - \\
\hline Ö4 & 23 & Erkek & Gürcistan & Yok & Market Uygulamaları \\
\hline Ö5 & 20 & Erkek & İran & Yok & Youtube \\
\hline Ö6 & 22 & Erkek & Fas & Yok & Youtube \\
\hline Ö7 & 20 & Kadın & İran & Yok & - \\
\hline Ö8 & 18 & Kadın & Moğolistan & Yok & - \\
\hline
\end{tabular}

Tablo 2'de ise yabancı öğrencilerin demografik bilgileri, uzaktan eğitim geçmişi ve öğretim teknolojilerini kullanma durumlarına yer verilmiştir. Demografik bilgiler katılımcılar hakkında bilgilendirmek amaçlı olup uzaktan eğitim deneyimleri ve demografik bilgiler çerçevesinde değerlendirilmiştir. Çalışmada ÖE1 ve ÖE3’ün öğrencileriyle görüşme yapılmıştır. B2 seviyesindeki öğrenciler hâlihazırda eğitim alan en yüksek seviyedeki öğrenciler olduğu için bu öğrenci grubu tercih edilmiştir.

\section{Veri toplama araçları}

Araştırma kapsamında kullanılan veri toplama araçları, yarı-yapılandırılmış gözlem formu ve yarıyapılandırılmış görüşme formudur. Uzaktan eğitim sürecine yönelik öğretim elemanlarıyla ve öğrencilerle mülakatlar yapılmıştır. Görüşme, insanların durumlara veya olaylara yükledikleri anlamları öğrenmek ve bakış açılarını ortaya çıarmak amacıyla yapılan çok boyutlu bir veri toplama aracıdır (Patton, 2014). Uzaktan eğitime yönelik yargılar ve deneyimler görüşme yoluyla ortaya

Adres $\mid$ Address

RumeliDE Dil ve Edebiyat Araştırmaları Dergisi $\quad$ RumeliDE Journal of Language and Literature Studies Osmanağa Mahallesi, Mürver Çiçeği Sokak, No:14/8 Osmanağa Mahallesi, Mürver Çiçeği Sokak, No:14/8

Kadıköy - İSTANBUL / TÜRKIYE 34714 Kadıköy - ISTANBUL / TURKEY 34714 e-posta: editor@rumelide.com e-mail: editor@rumelide.com,

tel: +90 505 7958124, +90 2167730616 phone: +90 505 7958124, +90 2167730616 
çıkarılmaya çalışılmıştır. Görüşme türlerinden yarı-yapılandırılmış görüşme formu düzenlenmiş ve bire bir görüşmeler yapılmıştır. Yarı-yapılandırılmış görüşme soruları önceden planlanmış ve görüşmenin ilerleyişine göre yeni sorular ve sondalar eklenmiştir. İlgili form Ek 1'de verilmiştir.

Çalışmada kullanılan diğer bir veri toplama aracı olan yarı-yapılandırılmış gözlem formu, literatürden hareketle oluşturulan başlıklar ve onlarla ilgili yansıtıcı yorumlar şeklinde düzenlenmiştir. İlgili form Ek 2'de verilmiştir. Araştırmacı uzaktan eğitim ortamında katılımcı gözlemci olarak yer almıştır. Bu gözlem formatında "araştırmacının faaliyeti incelenen grup tarafından bilinmektedir" (Meriam, 2019: 118). Bu çerçevede araştırmacı 2 ders saati gözlem yapmıştır. Araştırmacı; ortamı, ders sürecini, öğretim elemanını ve öğrenciyi önceden yapılandırdığı forma göre değerlendirmiştir.

\section{Veri analizi}

$\mathrm{Bu}$ çalışmada kullanılan analiz çeşidi içerik analizidir. İçerik analizi, kategoriler oluşturmayı ve bu kategorilerin ilişkili olduğu durumları ele alarak analiz yapmayı amaçlar (Silverman, 2018). İçerik analizi yoluyla bağlam içinde yer alan gerçekler ortaya çıkarılmaya çalışılır (Yıldırım \& Şimşek, 2018). $\mathrm{Bu}$ amaçla kodlama işlemi yapılmaktadır. Bir cümleyi ya da sözcük grubunu temsil etmek ya da tanımlamak adına kullanılan kısa ifadeler kodlardır (Saldana, 2019). Bu araştırma kapsamında kodlar, ardından kategoriler ve son olarak temalara ulaşmak hedeflenmiştir. Uzaktan eğitimle yabancı dil olarak Türkçe öğretimiyle ilgili elde edilen verilerden, tümevarımsal bir anlayışla parçadan anlamlı bütünler oluşturarak, konuyla ilgili temalara ulaşılmaya çalışılmıştır.

\section{Geçerlik ve güvenirlik}

Araştırma sürecinde geçerlik ve güvenirliğe yönelik bazı önlemler alınmıştır. Nitel araştırmalarda iç geçerlik ya da inandırıcılık kavramı, elde edilen verilerin ve yorumların gerçekliği yansıtma derecesiyle ilgilidir (Yıldırım \& Şimşek, 2018). Çalışmada veri çeşitlemesi yoluna gidilmiştir. Öğretim elemanlarının ve öğrencilerin uzaktan eğitimle ilgili görüşleri için mülakatlar yapılmıştır. Daha sonra araştırmacı, derslerde katılımcı gözlemci olarak yer almış ve ortamda doğrudan gözlem yapma firsatı bulmuştur. Gözlem ve görüşmeyle veriler çeşitlendirilerek gerçekliğe ulaşma derecesi artırılmaya çalışılmıştır.

Araştırmanın veri toplama araçlarından yarı yapılandırılmış görüşme formları, iki alan uzmanından dönüt alınarak hazırlanmıştır. Yarı-yapılandırılmış gözlem formu ise literatürde uzaktan eğitimle ilgili yapılan çalışmalardan hareketle belli başlıklarla sınırlandırılmıştır.

Meriam (2019), nitel araştırmalarda genellenebilirlik kavramının örneklem seçimiyle ilgili olduğuna ve ortam merkezli şekilde değerlendirilmesi gerektiğine temas eder. Örnek olarak çalışma kapsamında yabancı dil olarak Türkçe öğreten 4 öğretim elemanı A2, B1 ve B2 düzeyinde eğitim vermektedir. Bu çerçevede A1 ve $\mathrm{C} 1$ seviyesinde bir yorum yapılamazken ilgili düzeyde eğitim veren öğretim elemanlarının benzer deneyimlerle, sorunlarla veya avantajlarla karşılaşabileceğine ilişkin bir iddiada bulunulabilir.

Araştırma kapsamında veriler yorumlanırken olası yanlılığı önlemek ve iç güvenirliği/tutarlığı artırmak amacıyla kodlayıcı güvenirliğine başvurulmuştur. Kodlayıcı güvenirliği, birden fazla kodlayıcının aynı verileri birbirinden habersiz olarak çözümlemesi sonucunda elde edilen cevapların kararlılık\uyum derecesinin incelenmesidir (Creswell, 2018). Öğretim elemanları ve öğrencilerle yapılan mülakatların yazıya geçirilmesinden sonra farklı bir araştırmacının da verileri kodlaması 
istenmiştir. Yöneltilen sorular kapsamında alınan yanıtlara benzer kodlar verildiği gözlemlenmiştir. 2 farklı transkripsiyon işleminden sonra ortak kanaatle kod, kategori ve temalar oluşturulmuştur.

\section{Bulgular}

Bu bölümde araştırma sorularını cevaplamak üzere, veri toplama araçlarından elde edilen verilere uygulanan içerik analizi sonuçları sunulmuştur.

\section{1. Öğretim elemanlarından elde edilen bulgular}

Tablo 3. Uzaktan eğitimle yabancllara Türkçe öğretiminde öğretim elemanlarının görüşleri

\begin{tabular}{|c|c|c|}
\hline Tema & Kategori & Kod \\
\hline \multirow{5}{*}{$\begin{array}{l}\text { Uzaktan eğitimin öğretim } \\
\text { sürecindeki yansımaları }\end{array}$} & \multirow[t]{3}{*}{ Olumlu yansimalar } & Mekândan bağımsız olma \\
\hline & & Öğrenmede alternatifler \\
\hline & & Ekonomik çlktılar \\
\hline & \multirow{2}{*}{$\begin{array}{l}\text { Olumsuz } \\
\text { yansimalar }\end{array}$} & Ortam Etkisi \\
\hline & & Bağlantı problemi \\
\hline \multirow{4}{*}{$\begin{array}{l}\text { Uzaktan eğitimde öğretim } \\
\text { elemanının beklentileri }\end{array}$} & \multirow[t]{2}{*}{ Mesleki yeterlikler } & Tecrübe kazanma \\
\hline & & Teknolojik yeterliklerini iyileştirme \\
\hline & \multirow[t]{2}{*}{$\begin{array}{l}\text { Öğrencilerin } \\
\text { yeterlikleri }\end{array}$} & Kendini geliştirmek \\
\hline & & Devamlılık \\
\hline \multirow{6}{*}{$\begin{array}{l}\text { Uzaktan eğitimle temel dil } \\
\text { becerilerindeki kazanımlar }\end{array}$} & \multirow{3}{*}{$\begin{array}{l}\text { Aksaması } \\
\text { muhtemel } \\
\text { beceriler }\end{array}$} & Yazma \\
\hline & & Konuşma \\
\hline & & Gramer \\
\hline & \multirow{3}{*}{$\begin{array}{l}\text { Gelişim sağlanması } \\
\text { muhtemel } \\
\text { beceriler }\end{array}$} & Okuma \\
\hline & & Dinleme \\
\hline & & Konuşma \\
\hline
\end{tabular}

\subsection{Uzaktan eğitimin öğretim sürecindeki yansımaları}

Öğretim elemanları yabancı dil olarak Türkçe öğretiminin uzaktan eğitimle yürütülmesinin yansımalarını değerlendirmiştir. Uzaktan eğitimin öğretim sürecine olumlu ve olumsuz yansımaları

\footnotetext{
Adres $\mid$ Address

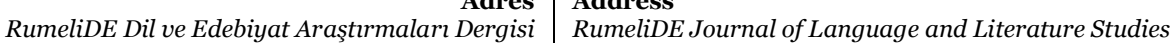
Osmanağa Mahallesi, Mürver Çiçeği Sokak, No:14/8 Osmanağa Mahallesi, Mürver Çiçeği Sokak, No:14/8

Kadıköy - İSTANBUL / TÜRKIYE 34714 Kadıköy - ISTANBUL / TURKEY 34714 e-posta: editor@rumelide.com e-mail: editor@rumelide.com

tel: +90 505 7958124, +90 2167730616 phone: +90 505 7958124, +90 2167730616
} 
kategorisinde bu durum ele alınmıştır. Uzaktan eğitimin "mekândan bağımsız olma” özelliği, her an erişilebilirlik sağlanması, öğrenci ve öğretici için bir artı değer olarak görülmüştür.

ÖE2: "Dün mesela öğrencilerle akşam sinav uygulaması yaptık bizim Türk dilcilerle ve oturdum dün gece 12 buçuk 1 civarındaydı. Şimdi ben o saatte bile öğrencilerle yollar aşıp uygulama yaptirabiliyorum, sinf denen bir zaman arayacak bir ortam yok"

Öğrencilerle fizikî mesafenin azalması, eğitimin çevrim içi oluşu; öğrenmede alternatif yaklaşımların öne çlkmasına yol açmıştır. Öğrencilerin ilgi ve dikkatlerini cezbedecek uygulamalar ve sağlanan materyallerin öğretim elemanların tarafından uzaktan eğitime yönelik artı değer olarak görüldüğü aktarlabilir.

ÖE2: "Online derslerin, bilgisayar ortamindaki dersin, bir öğrenciye çok farkh yönler ile ders anlatma ve daha çok materyal kullanarak dersi zenginleştirme özelliği fazla. Özellikle şu dönemde dersleri daha etkili işleyebildiğimi görüyorum.”

Uzaktan eğitimle ilgili olarak ayrıca ekonomik çlktılar üzerinde durulmuştur. Uzaktan eğitimin hem öğrenci hem de öğretim elemanları için maddi açıdan sağlayacağı faydalara temas edilmiştir.

ÖE2: "Olumlu çıktılar olacak. Bunların en büyüğü ekonomik çıtıdır. Ekonomik olarak çocuklar ve biz de aynı şekilde bir yerden belli bir yere giderken harcayacağını parayı başka şeyler için harcayabileceğiz."

Öğretim elemanlarının uzaktan eğitimle yabancı dil olarak Türkçe öğretimi sürecinde gördükleri problemler öğretim sürecindeki olumsuz yansımalar olarak değerlendirilmiştir. Ortam etkisi ve bağlantı probleminin öğretim sürecinin sağlıklı bir şekilde işleyişini engellediği ifade edilmiştir. Ortam etkisi, uzaktan eğitimi yüz yüze eğitim ortamıyla karş̧laştırarak olumsuzlaştırma ve buna bağlı adaptasyon problemleri olarak yansımıştır.

ÖE3: Uzaktan eğitim sınıf ortamı gibi değil. Sinıf ortamında daha farkh oluyor. Tabii daha canlı daha öğrencilerle kaynaşabiliyorsun. Daha iyi oluyor. Hiç beğenmedim.

ÖE2: Yani bilgisayar bir soğuk madde içinde birçok parça var ve hepsi soğuk. Ruh yok ruhsuz bir eğitim oluyor.

Ders esnasında bağlantı kaynaklı aksaklıkların sınıf ortamında iletişim eksikliği ve devamlılık konularında sıkıntı oluşturduğu belirtilmiştir. İnternet ağının zayıf olması ve uygulamadan kaynaklı iletişim sıkıntıları bu durumun önünü açmıştır.

ÖE3: Hepsi bir anda konuşmaya başlayınca mesela sesler karışıyor ben de otomatik kapatmak zorunda kalyyorum. Tek tek cevap veriyorum. Onun da derste bir yarar olmuyor, iletişim eksik kaltyor.

\subsection{Uzaktan eğitimde öğretim elemanının beklentileri}

Öğretim elemanları uzaktan eğitim deneyimleri çerçevesinde geleceğe dönük hedef yeterliliklerini aktarmışlardır. Kendi mesleki yeterlikleri ve öğrencilerden bekledikleri yeterlikler kapsamında uzaktan eğitimle yabancı dil olarak Türkçe öğretiminin başarıya ulaşabileceği düşünülmektedir. Tecrübe kazanma noktasında mesleki yeterliklerin zaman içinde gelişebileceğine inanılmaktadır

ÖE3: "Tabi ki biz de acemiyiz yavaş yavaş alışacağız bu sisteme. Belki zamanla daha da iyi olabiliriz.

\begin{tabular}{r|l} 
Adres & Address \\
RumeliDE Dil ve Edebiyat Araşttrmalar Dergisi & RumeliDE Journal of Language and Literature Studies \\
Osmanağa Mahallesi, Mürver Çiçeği Sokak, No:14/8 & Osmanağa Mahallesi, Mürver Çiçeği Sokak, No:14/8 \\
Kadıköy - İSTANBUL / TÜRKIYE 34714 & Kadıköy - ISTANBUL / TURKEY 34714 \\
e-posta: editor@rumelide.com & e-mail: editor@rumelide.com, \\
phone: +90 505 7958124, +90 2167730616
\end{tabular}


Aynı şekilde zaman içerisinde uzaktan eğitimin imkânlarına aşina olmanın, teknolojik yeterlikleri iyileştirme konusunda da gelişim sağlanmasına katkıda bulunacağı düşünülmektedir.

ÖE1: "Bu aşamada uzaktan eğitimle Türkçe öğretimi her ne kadar zor olsa da imkânlar kullanarak bu uğurda çalışmak ve devamhlığı sağlayarak başarılı olmak hedefimiz açıkçası."

Öğreticilerin öğrencilerin uzaktan eğitime ve öğretim sürecine ilişkin geliştirmesini bekledikleri yeterlikler öz disiplin ve devamlılıktır. Öğrencinin öz disipline sahip olması, gelişimi için çabalaması ile ilişkilendirilmiştir. Öğretim elemanları tek taraflı çabaların sonuçsuz kalacağı kanaatindedir.

ÖE4 "Tek tarafl olmaz, tarafların çabasıyla ancak sonuca ulaşabiliriz. Ben uğraştığım kadar öğrenci de kendisi için çaba göstermeli, işte kendini geliştirmek için uğraşmal.."

Derslere ve ders içinde verilen görevlere yönelik devamlılık sağlanması, Türkçe öğretiminin başarıya ulaşması için diğer bir gerekliliktir.

ÖE1“Ben öğrencilerin kathlımı sağlandiğı, sağlkkl ve düzenli bir devamlllk olduğu takdirde, öğrencilere gerek elektronik ortamda gönderdiğim belgelerle video konferans ses sisteminin hani, bize sağladığ faydalar ve video görüntülerin sağladığı faydalarla öğrencilere yüz yüze eğitimdeki kadar yakın olup sorunlarıyla ilgilenme firsatı bulacağımızı düşünüyorum."

\subsection{Uzaktan eğitimle Türkçe öğretiminde dil becerileri}

Yabancı dil olarak Türkçe öğretiminde dil yeterliklerinde aksayacak ve gelişim sağlanacak temel dil becerilerine yer verilmiştir. Öğreticiler, yürüttükleri derslerde hangi dil becerileri için avantajlar ve dezavantajların bulunduğunu ifade etmişler ve deneyimlerinden hareketle geleceğe dönük öngörülerini sunmuşlardır. Yazma, konuşma ve gramer öğretimindeki yaşanacak aksamalar, uzaktan eğitimin özelliklerine bağlı olarak değerlendirilmiştir.

ÖE3: "Zoom sistemine telefonla girdiklerini düşün. O anda ben bir şey yazmak istedim. Telefon otomatik düzeltiyor kelimeleri, öğrencilere de düzeltecek o yüzden sikıntı olur. Yani yeterince kontrol edemeyiz. Otomatik düzeltme olduğu için de yanlıs yapıp yapmadıklarım da fark edemeyecekler. Bu teknoloji, bu anlamda onlara faydah değil yetersiz."

Akıllı telefonların yazma psikomotor becerilere ket vuracağı belirtilmiştir. Farklı bir görüşte ise öğretmen ekseninden ayrılan becerilerin gelişiminin aksayacağı belirtilmektedir. Uzaktan eğitimle öğreticiye yüklenen sorumlulukların artmasının olumsuz etkileri olduğu görüşü de belirtilmiştir.

ÖE4: "Okuma ve dil bilgisi benim eksenimde olan dersler o yüzden gerisi öğrenciye kalyyor. Ön planda ben olduğun için yani birinin gözetimlerinde olduğu için daha kontrollü ancak işi biraz öğrencilerin inisiyatifine buraktığımız becerilerde konuşma ve yazma gibi daha az gelişim sağlanacağını düşünüyorum”

Öğretim elemanları öğrencilerin gramer konularını yüz yüze eğitime göre daha yavaş öğreneceklerini düşünmektedirler. Öğrenmenin hızının düşmesi, gramer öğretiminde görülebilecek bir aksaklık olarak ele alınmıştır.

ÖE1: "Hani zorlandikları bazı gramer konuları olabilir ama tamamen kazanamayacaklar diye düşünüyorum. Normale göre zaman alr diye düşünüyorum.”

Okuma ve dinlemenin uzaktan eğitimde verimli geçecek dersler arasında olduğu ifade edilmiştir. Temel dil becerilerinden anlama becerileri için eş zamanlı olarak yürütülen derslerin verimli olduğu düşünülmektedir.

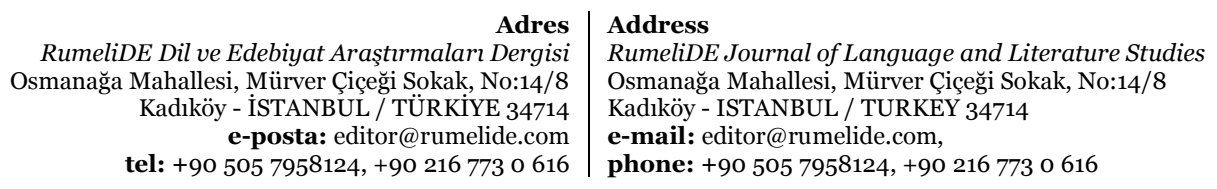


ÖE1: "Anlama becerilerinin okuma ve dinleme becerilerinin gelişeceği konusunda inanctm var diyelim."

Konuşma becerisi için iki farklı görüş verilmiştir. Konuşma becerisinin kazanımlarının aksayacağını düşünen öğretim elemanları bulunurken kazanım sağlanacak tek beceri olabilme ihtimali üzerinde duran görüşler de bulunmaktadır.

ÖE3: "Dönemin sonunda konuşma dersi için onda bir kazanımları olabilir."

\section{2. Öğrencilerden elde edilen bulgular}

Tablo 4. Uzaktan eğitimle yabancllara Türkçe öğretiminde öğrenci görüşleri

\begin{tabular}{|c|c|c|}
\hline Tema & Kategori & Kod \\
\hline \multirow{4}{*}{$\begin{array}{l}\text { Uzaktan } \\
\text { Ë̆itimle } \\
\text { Öğretim } \\
\text { süreciyle ilgili } \\
\text { düşünceler }\end{array}$} & \multirow[t]{2}{*}{ Faydalı olduğu düşünülen yönleri } & Öğrenme motivasyonunu geliştirme \\
\hline & & Bireysel öğrenme yeterliklerini artırma \\
\hline & \multirow[t]{2}{*}{ Zayıf olduğu düşünülen yönleri } & Teknik aksakların derse erişimi engellemesi \\
\hline & & Sosyal ortam eksikliği \\
\hline \multirow{3}{*}{$\begin{array}{l}\text { Uzaktan } \\
\text { Ĕgitimde } \\
\text { İletişim }\end{array}$} & \multirow[t]{2}{*}{ Ders içi sınıf iletişimi } & Öğreticiden dönüt alma \\
\hline & & Öğrencilerin katılım göstermesi \\
\hline & Ders dışı sınıf iletişimi & Ödev değerlendirme \\
\hline \multirow{6}{*}{$\begin{array}{l}\text { Uzaktan } \\
\text { eğitimle temel } \\
\text { dil } \\
\text { becerilerindeki } \\
\text { kazanımlar }\end{array}$} & \multirow[t]{3}{*}{ Aksaması muhtemel beceriler } & Gramer \\
\hline & & Yazma \\
\hline & & Konuşma \\
\hline & \multirow{3}{*}{$\begin{array}{l}\text { Gelişim } \\
\text { beceriler }\end{array}$} & Okuma \\
\hline & & Dinleme \\
\hline & & Yazma \\
\hline
\end{tabular}

\subsection{Uzaktan eğitimle öğretim süreciyle ilgili düşünceler}

Öğrencilerin uzaktan eğitimle yürütülen öğretim süreciyle ilgili düşünceleri çeşitlilik göstermiştir. Uzaktan eğitimin kendilerine faydalı olduğunu düşündükleri yönleri, öğrenme motivasyonunu geliştirme ve bireysel öğrenme yeterliklerini artırma şeklindedir. Yabancı öğrencilerin öğrenme motivasyonlarının artmasında, sınıftan uzak olmanın oluşturduğu açı̆̆ı kapatma çabasının onları çalışmaya ittiği düşünülmektedir. Öğrenme ortamının fizikî olarak sınıftan uzaklaşması öğrencilerin bireysel öğrenme yeterliklerini geliştirmeye sevk etmiştir.

Ö4 "Üniversitedeyken, sinıfta bu kadar çalşmıyordum. Çünkü orada öğreniyordum. Şimdi çok çalışıyorum."

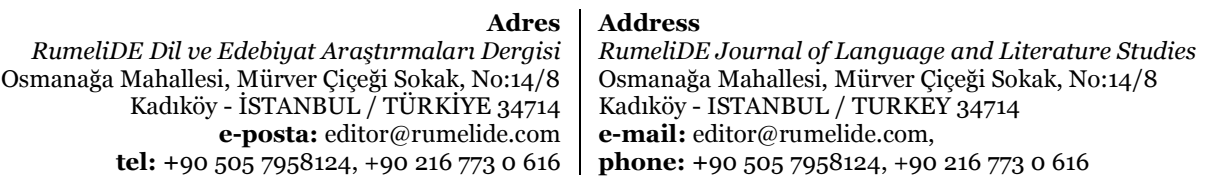


Ö5 Yani bir kimse gelsin sadece dinlesin, bu iyi olmaz. Ödevleri yapsın, evde çahşsın o zaman iyi olacak"

Ö6 "Derslere önceden hazırlı yapıyoruz, bu şekilde uzaktan eğitim daha iyi."

Uzaktan eğitimle ilgili tespit edilen belirgin sorunlardan biri, internet bağlantısıyla erişim sağlanan ders ortamında bağlantı problemleri yaşanmasıdır. Öğrenciler derse katılım sağlama ve dolayısıyla öğrenim sürecine dâhil olma noktasında sıkıntı yaşamaktadır.

Ö3“Ben şimdi Gürcistan’a dönünce köye gittim. Yağmur yağınca problem oldu. Bağlantıda çok problem vardl. O zaman derse giremiyordum.”

Öğrencilerin ortama yönelik değerlendirdikleri diğer bir zafiyet ise sosyalleşmeye yönelik olmuştur. Sınıf ortamındaki sosyal yapının çevrim içi derslerde bulunamaması, öğrencileri uzaktan eğitimin etkililiğini sorgulamaya yöneltmiştir.

Ö8: “Sinıftaki gibi samimi olsak daha iyi olur. Yani bu eğitim yüz yüze değil, etkili değil.”

\subsection{Uzaktan eğitimde iletişim}

Ders içi ve ders dışı sınıf iletişimi, uzaktan öğretim kapsamında değerlendirilmiştir. Derste öğrencilerin sorularına öğreticilerinden dönüt alabilmesi öğrenmenin gerçekleşmesi için önemli bir unsurdur. Görüşmelerden ortaya çıan öğreticiden dönüt alma koduna ilişkin şu ifadelere yer verilmiştir:

Ö2: "Hocamızla iletişim kurmada sıkntı yok. Hocamızla strayla konuşuyoruz o da cevap veriyor ama kendi aramızda konuşmamız kötü. Sesler birbirine karışıyor.”

Öğrencilerin derse katılımıyla ilgili Ö2'nin görüşlerinden hareketle öğrencilerin kendi arasındaki iletişimin sınırlı olduğu görülmektedir. Ders esnasında öğrencilerin derse ne düzeyde ve nasıl katılım gösterdikleri, ders içi iletişimle ilgili diğer bir kod olarak belirlenmiştir.

Ö5: "Derse 20-24 kişi katılyyoruz. Derslerde kitaptan gideriz. Hoca herkesin sesini kapatıyor. Sirayla sorulara cevap veriyor."

Sınıf içindeki iletişimin yanı sıra ders dışında da öğrenci ve öğreticilerin haberleştiği tespit edilmiştir. Bu iletişimin öğretim elemanı tarafından ödevleri kontrol etmek üzere yönetildiği görülmüştür:

Ö1: “Whatsapp'ta sınıf grubumuz var. Hocamıza yaptığımız ödevlerin fotoğrafinı çekip gönderiyoruz. Hocamız sorunlar işaretliyor ve bize geri gönderiyor.”

\subsection{Uzaktan eğitimle temel dil becerilerindeki kazanımlar}

Temel dil becerilerindeki kazanımlar öğretim elemanlarının yanı sıra öğrencilerin bakış açısıyla da değerlendirmeye tabi tutulmuştur. Öğrencilerden de öğrenme sürecindeki temel dil becerilerinden okuma, dinleme, konuşma ve yazma derslerinden aldıkları verimi ifade etmeleri istenmiştir. Aynı zamanda gramer konularının ele alındığı temel Türkçe derslerine yönelik de görüşler alınmıştır.

Öğrencilerin gramer, yazma ve konuşma derslerinde sıkıntı yaşadıkları gözlenmiştir. Yazma becerisinde pratik eksikliğinin problem yaşamalarının kaynağı olduğu ifade edilmiştir.

Ö5: "Yazma sıkıntılı hocam. Yazma hakkında... Yazmayı unutuyorum hocam."

\begin{tabular}{r|l} 
Adres & Address \\
RumeliDE Dil ve Edebiyat Araşttrmaları Dergisi & RumeliDE Journal of Language and Literature Studies \\
Osmanağa Mahallesi, Mürver Çiçeği Sokak, No:14/8 & Osmanağa Mahallesi, Mürver Çiçeği Sokak, No:14/8 \\
Kadıköy - İSTANBUL / TÜRKIYY 34714 & Kadıköy - ISTANBUL / TURKEY 34714 \\
e-posta: editor@rumelide.com & e-mail: editor@rumelide.com, \\
phone: +90 505 7958124, +90 2167730616
\end{tabular}


Temel Türkçe derslerinde hedef dile yönelik gramer kurallarının öğrenilemediği belirtilmiştir.

Ö2: "Dilbilgisi zor oluyor hocam. Gramer dersleri iyi değil, anlamıyorum. Diğerlerinde problem yok."

Konuşmanın gelişiminde çevre faktörünü göz önünde bulundurarak yüz yüze eğitime göre dezavantajları anlatılmıştır. Öğrencilerin, sınıfta, yurtta ve diğer sosyal alanlarda Türkçe konuşma oranlarının azalmasından yana kaygllar dile getirilmiştir.

Ö8: "Konuşma iyi değil hocam. Konuşmada hoca seslerimizi kapatıyor. Strayla konuşuyoruz, birbirimizle konuşma yok."“... oda arkadaşlarım yok onlarla konuşuyordum. Yine gelirlerse konuşma firsatım olacak."

Öğrenciler dinleme ve okuma becerilerinde aşama kaydettiklerini düşünmektedirler.

Ö7: "Okuma derslerimiz iyi. Kitaptan birkaç tane okumalarımı oluyor ve her paragrafi bir kişi okuyor. Bilmediklerimizi soruyoruz."

Ö2: "Dil becerileri için... dinlememiz ilerliyor."

Anlatma becerilerinden yazmada olumsuz görüşlerin yanı sıra kazanım sağlandığına yönelik görüşler de bulunmaktadır. Yazma dersinin alternatif olarak uzaktan eğitime entegre edilmesiyle bu görüşlerin ortaya çıktığı görülmüştür.

Ö8: "Yazma ödevini ben yaptıktan sonra hoca düzeltip bana yolluyor. Nerede hata yaptıysan onlarl düzeltiyorum. Yazma güzel gidiyor."

\section{Gözlemden elde edilen bulgular}

Uzaktan eğitimle yabancılara Türkçe öğretimde derslerin nasıl yürütüldüğünü incelemek için araştırma kapsamında $2 \mathrm{kez}$ gözlem yapılmıştır. Gözlem yapılan dersler ÖE1 ve ÖE4 öğretim elemanlarının dersinde uzaktan eğitim ortamının öğrenci ve öğreticinin merkezli değerlendirmesini kapsamaktadır.

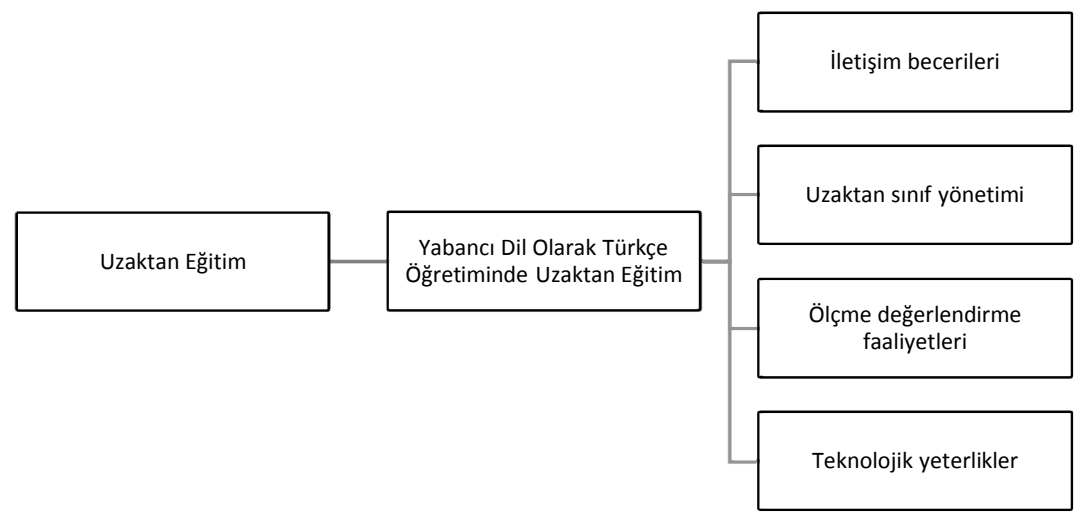

Şekil 1: Gözlem değerlendirme formunda kullanılan tema, kategori ve kodlar

\section{1. İletișim becerileri}

Gözlem formundan elde edilen sonuçlar çerçevesinde ÖE1’in sınıfında öğrencilerin aktif iletişim kurduğu ve kaygılı bir ortamın olmadı̆̆ı gözlemlenmiştir.

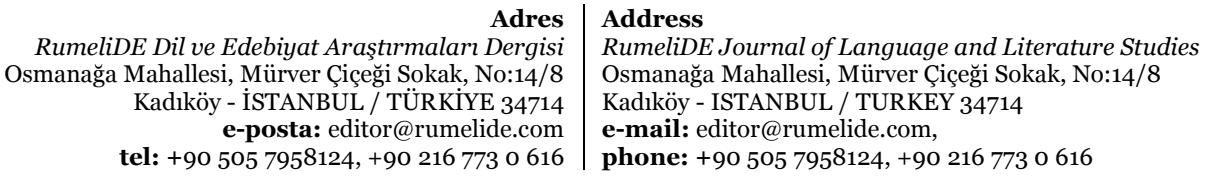


"Uzaktan öğretim ortamında aktif katılım sağlayan, Türkçe düzeylerine göre (B2) kendini ifade etmek konusunda başarıl denebilecek bir öğrenci profili var. Türkçe öğreticisi tane tane ve kısa cümlelerle, öğrenci seviyelerine dikkat ederek konuşuyor.” (ÖE1-S)

ÖE4’ün sınıfında da benzer olarak pozitif bir ortam olduğu ifade edilmiş olup, etkileşim noktasında diğer sınıfta görüntü ve sesli katılım mevcutken bu sınıfta sadece sesle katılımın olduğu görülmüştür. Cinsiyete göre konuşma eğilimlerinde farklılık olduğu saptanmıştır.

"Ders ortamlarında kız öğrencilerin az konuşma eğiliminde olduğu gözlenen diğer bir durumdur. Kız öğrenciler kısa cevaplar veriyor, uzun konuşmayı tercih etmiyorlar.”(ÖE4-S)

\subsection{Uzaktan sinıf yönetimi}

İki sınıfta da demokratik bir ortam olduğu gözlemci tarafından ifade edilmiştir. Herkese sırayla söz verilmesi ve hemen hemen bütün öğrencilerin derse katılımının sağlanması, özellikle ÖEı’in sınıfında daha baskın bir durumdur.

"Derste münazara tipi, iki görüşlerin karşı karşıya getirilip sırasıyla farkl görüşlere yer verme dersin akıcılı̆̆m olumlu yönde etkiledi. Herkes konuştu ve düşüncelerini anlatma firsatı buldu."(ÖE1-S)

Ders esnasında zaman yönteminin etkin bir şekilde sağlandığı görülmüştür. Planlı programlı yapılan iki ders gözlemlenmiştir.

"Ders önceden planlanmış gibi ilerliyor. Öğrencilerin uzun konuşmalarını hoca kısaca özetleyip toparlyyor." (ÖE1-S)

“Zaman yönetimi başarll, konu sona erince ders saati tamamlanmıştı.”(ÖE4-S)

\section{3. Ölçme değerlendirme faaliyetleri}

Ders esnasında soru-cevap, cevaplara dönüt verme ve soru sorma sıklı̆̆ı konuları değerlendirilmiştir. ÖE1 dersinde okuma-konuşma becerisi üzerinden gidildiği için daha çok soru-cevap olduğu tespit edilmiştir.

Soru cevapla derse başlandı. "Spor müsabakalarında kazanmak mı yoksa katılmak mı önemlidir?” sorusuyla öğrencilerin bir cevap tercihinde bulunmalar istenmiștir. Öğrenciler kazanmak ya da katılmak üzerine belirttikleri görüşleri günlük hayattan örnekler vererek açıklamaya çalıştılar. (ÖE1-S)

ÖE4’te soruları cevaplayan öğrencileri genellikle aynıdır. Ancak ders esnasında hocanın soru sorma ve öğrenci sorularına cevap verme performansının yüksek olduğu ifade edilmiştir. "Öğrenciler dilbilgisiyle ilgili soru soruyor. Bunun dışında derste konuşan öğrenciler belli kişiler...”

\subsection{Teknolojik yeterlikler}

Teknolojik yeterlikler konusunda 2 sınıf ortamı da "sınırlı" olarak nitelendirilebilir. Ders materyali olarak Yunus Emre Türkçe Seti PDF olarak açıldı (ÖE1-S ÖE4-S). Materyal çeşitleme yoluna gidilmediği ve daha çok hocaların güvenli alanlarında kalma eğilimleri olduğu görülmüştür. Ders esnasında ÖE4 öğretim elemanı "telefonundan açtığı görseli kameraya tutarak öğrenciye kelime anlatmaya çalıştı" ancak bunu bilgisayar üzerinden yapabilecekken yüz yüze sını ortamı gibi düşünerek hareket etmiştir. Öte yandan ÖE4'ün ders esnasında bağlantısı kesilmiş ancak hemen sınıfı tekrar toplayarak derse devam etmiştir.

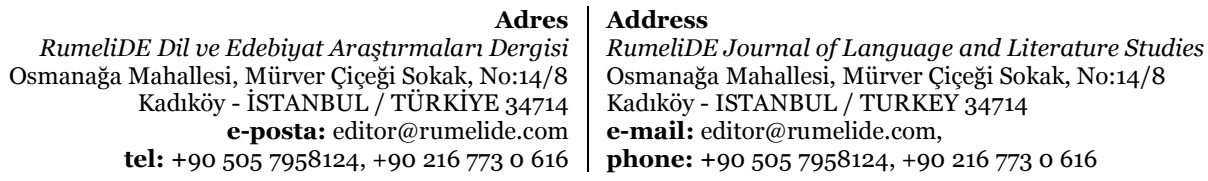


Toplant bir kez kesildi. 2 dakika içinde geri dönüş sağlandı. Hoca bu anlamda paniğe kapılmadan toplantıya dönüşü sağladı ve dersine kaldığı yerden devam etti. (ÖE4-S)

$\mathrm{Bu}$ çerçevede teknolojik yeterlikler konunda hocaların dersi devam ettirdiği ama risk almadığı ya da yeni şeyler denemekten kaçındığı görülmüştür.

\section{Tartışma, sonuç ve öneriler}

Yabancı dil olarak Türkçe öğretiminin uzaktan eğitimle yürütülmesinin öğretim sürecine ilişkin olumlu ve olumsuz yansımaları bulunmaktadır. Öğretim sürecindeki olumlu yansımalarda öne çlkan sonuçlar; ekonomik çıktılar, öğrenmede alternatifler ve mekânsal bağımsızlık şeklinde sıralanabilir. Mekânsal açıdan bir ortama bağlı olmamak ekonomik çıtılarla da ilişkilendirilmiştir. Ekonomik açıdan öğrenciye ve öğreticiye gelen olumlu yansımalar, sosyal açıdan uzaktan eğitimin yansımalarıdır. Geleneksel öğretime göre daha düşük maliyetli olması, imkânları yetersiz olan öğrenciler için firsat eşitliği sağlamaktadır (Kandemir, 2014). Bu öğretim şekli, şartları uzaktan eğitim için uygun olan bireylere yönelik farklı bir opsiyon sunmaktadır. Diğer yandan sosyal medya araçlarını da kullanarak veri akışı sağlama noktasında alternatif sağlaması, öğretim elemanları tarafından olumlu bir yansıma olarak değerlendirilmiştir. Uzaktan eğitimin öğretim sürecindeki olumlu yönlerine odaklanan görüşler, daha önce çevrim içi derslerle ilgili deneyimi olan öğretim elemanlarından gelmiştir. Uzaktan eğitimle ilgili tecrübesi olan öğretim elemanları, tecrübesi olmayanlara göre bu eğitime karşı daha olumludur (Ulmer, Watson \& Derby, 2007). Elde edilen sonuçlar bu görüşü destekler niteliktedir.

Öğretim sürecindeki olumsuz yansımalar, ortam açısından ele alınmış; yüz yüze eğitimdeki gibi sosyal bir ortamın olmamasının etkilerinden bahsedilmiştir. Düzakın ve Yalçınkaya (2008) web tabanlı öğretimle ilgili yaptıkları çalışmada öğretim elemanlarının web tabanlı uzaktan eğitimin örgün eğitimin yerini alamayacağını düşündüklerini belirtmişlerdir. Öğretim elemanlarının bakış açılarının karşılaştırmalı olması, uzaktan eğitime dönük olumsuz bir etki yaratmıştır.

Beklentilerle ilgili elde edilen sonuçlarda öğretim elemanlarının süreci daha başarılı yürütme adına hedef belirledikleri ve gelecekte konuyla ilgili daha iyi olacaklarına yönelik inanç geliştirdikleri ifade edilebilir. Bu noktada öğretim elemanları, öğrencilerin de çaba ve yeterlilik göstermeleri beklentisindedirler.

Temel dil becerilerine yönelik elde edilen veriler, öğretim elemanları arasında tutarlı sonuçlara işaret etmemektedir. Konuşma becerisinde gelişim sağlanacağına ve başarıya ulaşılamayacağına yönelik düşünceler mevcuttur. Öğretim elemanlarından biri, bu noktada merkezde hocanın olmadığı becerilerin gelişemeyeceği şeklinde görüşlerini ifade etmiştir. Öğretici, öğrencilerin bireysel (özerk) öğrenme konusunda başarılı olamayacağı kanaatindedir. Öte yandan okuma, dinleme becerilerinde kazanım sağlanmasının mümkün olduğu ifade edilmiştir. Anlama becerilerinde gelişim sağlanacağı, konuşma da ise ortamın uygunluğundan kaynaklı başarı sağlanabileceği düşünülmektedir.

Öğretimde aksaklık yaşanacağı kanaatinde olunan becerilerin arasında özellikle yazmayla ilgili bütün öğretim elemanlarının kaygılı olduğu görülmüştür. Teknolojinin günlük hayatta pratiklik sağlayan özellikleri, öğrencilerin yazma becerilerini geliştirmede tersine bir etki yaratmıştır. Psikomotor ve bilişsel boyutta yazma etkinlikleri, öğrencilerin pratiklik kazanması açısından eksik kalmaktadır.

Öğrencilerin uzaktan eğitimle ilgili düşünceleri, özellikle bireysel öğrenme yeterliklerini artırma ve öğretim süreciyle ilgili motivasyonları geliştirme noktasında faydalı olduğu yönündedir. Öğrencilerin

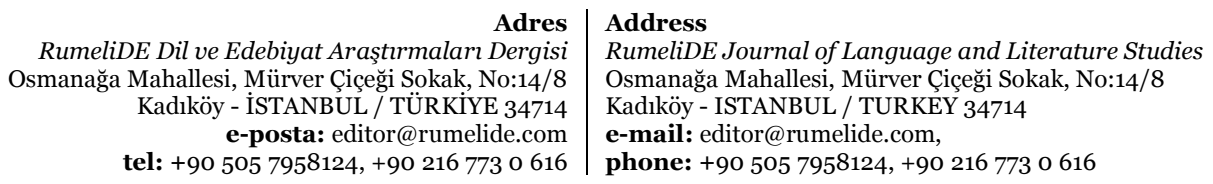


derslerde kendi sorumluklarını almaya istekli oldukları görülmektedir. Uzaktan eğitimde kullanılan öğrenme modelleri öğrenciye klasik eğitim modellerine göre daha fazla sorumluluk yüklemektedir (Eygü \& Karaman, 2013). Uzaktan eğitimle öğrencilere yüklenen sorumluluklar özerk öğrenme konusunda ilerleme kaydetmelerine katkıda bulunabilir. Öğrencilerin özerk öğrenme ile sorumluluklarının artması, süreci daha çok sahiplenmeleriyle sonuçlanır (Can, 2012). Bu durum da uzaktan öğretim konusunda olumlu düşünceler geliştirmelerine ve öğrenme performanslarının artmasına yol açabilir.

Öğretim elemanları ve öğrencilerin benzer görüşler sundukları düşünceler, sosyal ortam eksikliği ve teknik aksaklıkların derslerin verimini düşürmesi üzerine olmuştur. Sosyal etkileşim anlamında geleneksel öğretimin avantajları öne çıkmıştır.

Ders içi ve ders dışında öğrenci-öğretmen iletişiminin yüksek olduğu bulunmuştur. Öğrencilerin öğreticilerden ders içi ve ders dışında dönüt aldıkları görülmüştür. Öğrencilerin etkinliklerine yönelik dönüt almaları başarıları üzerinde etkili bir değişkendir (Öztürk, 2006). Öğretimin başarıya ulaşması ve uzaktan eğitimdeki fiziki mesafelerin kapatılması için iletişim önemli bir etkendir.

Temel dil becerilerine ilişkin anlatma becerilerinde yazma becerisinin gelişimiyle ilgili iki farklı görüş elde edilmiştir. Öğretim elemanlarının konuşma konusunda çeşitlenen görüşleri öğrencilerde yazma becerisinde farklılaşmıştır. Öte yandan öğrenciler konuşma becerisinde aksaklık yaşanacağını vurgulamıştırlar. Eroğlu ve Kalaycı (2020)'nin çalışmasında uzaktan eğitimle yapılan İngilizce derslerinde öğrencilerin konuşma becerisine yönelik pratiklik kazandıracak etkinlikler talep ettiği tespit edilmiştir. Yine İngilizce eğitimi üzerine yapılan çalışmada yazma, konuşma ve dinleme becerilerinin öğretiminde olumsuz sonuçlar alındığı, okuma ve dilbilgisi öğretiminde başarı sağlandığı belirtilmiştir (Ekmekçi, 2015). Öğrenciler okuma ve dinleme becerilerinde verim aldıklarını ifade etmişlerdir. Dilbilgisi ve dinleme konusunda verim alınacağıyla ilgili önceki çalışmalarla bağdaşmayan sonuçlar alınmıştır. Öte yandan anlatma becerileriyle ilgili uzaktan eğitimle ikinci dil öğretiminde problem yaşandığı doğrulanmıştır.

Temel dil becerilerine ilişkin çıkarılan sonuç özellikle anlatma becerilerini ve gramer öğretimini destekleyici uygulamalara ihtiyaç olduğudur. Bunlar öğrencilerin sürekli pratik yapmalarını teşvik edecek, anında dönüt verebilecek nitelikte etkileşimli materyaller olmalıdır.

Gözlem notlarıyla ilgili elde edilen veriler, öğrenci-öğretici iletişiminin pozitif ve etkileşimli bir ortam potansiyeli taşıdığını göstermektedir. Özellikle konuşma dersinde bu ortamın sağlanmasının, dersin yapısı göz önünde bulundurulduğunda, oldukça önemli bir konu olduğu gözlemlenebilir.

Zaman yönetimi ve uzaktan sınıf yönetimi açısında ÖE1 katılımcısının özellikleri öne çıkmakla birlikte iki sınıf ortamı da başarılı bulunmuştur. Ölçme değerlendirme konusunda A2 seviyesindeki öğrencilerin (ÖE4-S) aktif katılımı daha düşüktür. Bu durum öğrencilerin seviyelerine ve dersin okuma olmasına bağlanabilir.

Teknolojik yeterlikler konusunda sınıf ortamında sınırllıklar gözlemlenmiştir. Teknik aksaklıklarla başa çıkma noktasında başarı sağlanmıştır ancak materyallerde çeşitlilik yoktur. Bu durumu Bilgiç ve Tüzün (2015) tarafından teknik destek eksikliği ve teknolojik yeterliklerin eksik kalması bağlamında öğretim elemanlarının karşılaştıkları sorunlar arasında değerlendirilmiştir.

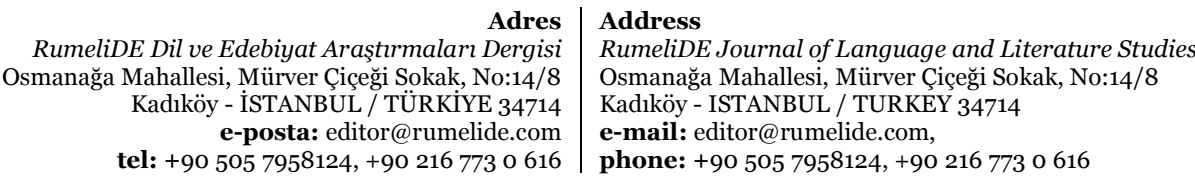


$\mathrm{Bu}$ çerçevede gözlem ve görüşmeler birlikte değerlendirdiğinde öğretim elemanlarının materyal konusunda çeşitliliğe vurgu yaptıkları ancak bunu uygulamada göstermedikleri sonucuna ulaşılmıştır. Ayrıca süreç içinde uzaktan eğitimle ilgili olumlu tutuma sahip hocaların derslerinin daha verimli geçtiği ve etkileşimin yüksek olduğu görülmüştür.

Uzaktan eğitimle yabancı dil olarak Türkçe öğretiminin öğrenci ve öğretim elemanı merkezli incelenmesiyle sürece ilişkin problemler belirlenmiş, geliştirilmesi gereken noktalar tespit edilmiştir. Bu kapsamda aşağıdaki önerilere yer verilmiştir:

1. Uzaktan eğitimle yürütülen yabancı dil olarak Türkçe programlarında anlatma becerilerine yönelik deneysel çalışmalar yapılmalıdır.

2. Yabancı dil olarak Türkçe öğretiminde konuşma etkinliklerini uzaktan eğitimle yürütmek için yeni uygulamalara ihtiyaç bulunmaktadır.

3. Yabancı dil olarak Türkçe öğretiminde özerk/bireysel öğrenmeyi destekleyici materyaller tasarlanmalıdır.

4. Öğretim elemanlarının çevrim içi derslerdeki teknolojik yeterliklerini geliştirmeye yönelik hizmet içi eğitimler yapılmalıdır.

5. Yabancı dil olarak Türkçe öğretiminde yazma becerisinin psikomotor boyutunu geliştirmek için etkinlikler düzenlenmelidir.

6. Gelecekte yabancı dil olarak Türkçe öğretiminde uzaktan eğitimle ilgili nicel eğilimli araştırmaların yapılması gerektiği düşünülmektedir.

\section{Kaynakça}

Adıyaman, Z. (2001). Uzaktan eğitim yoluyla yabancı dil öğretimi. The Turkish Online Journal of Educational Technology (TOJET), 1(11), 92-97.

Al, U., \& Madran, R. O. (2004). Web-based distance education systems: Required features and standards. Bilgi Dünyası, 5(2), 259-271.

Arrosagaray, M., González-Peiteado, M., Pino-Juste, M., \& Rodrīguez-López, B. (2019). A comparative study of Spanish adult students attitudes to ICT in classroom, blended and distance language learning modes. Computers \& Education, 134, 31-40.

Ateş, A., \& Altun, E. (2008). Bilgisayar öğretmeni adaylarının uzaktan eğitime yönelik tutumlarının çeşitli değişkenler açısından incelenmesi. Gazi University Journal of Gazi Educational Faculty (GUJGEF), 28(3), 125-145.

Balaman, F. (2018). Web Tabanlı Uzaktan Eğitim ile Geleneksel Eğitimin İnternet Programcllı̆g 2 Dersi Kapsamında Karşllaştırılması. Itobiad: Journal of the Human \& Social Science Researches, 7(2), 1173-1200.

Bilgiç, H. G., \& Tüzün, H. (2015). Yükseköğretim kurumları web tabanlı uzaktan eğitim programlarında yaşanan sorunlar. Açlköğretim Uygulamaları ve Araştırmaları Dergisi, 1(3), 26-50.

Bozkurt, A. (2017). Türkiye'de uzaktan eğitimin dünü, bugünü ve yarını. Açıköğretim Uygulamaları ve Araştırmaları Dergisi, 3(2), 85-124.

Can, T. (2012). Yabancı dil öğretimi bağlamında öğrenen özerkliğinin sanal öğrenme ortamları yoluyla desteklenmesi. Hasan Ali Yücel Ĕ̈itim Fakültesi Dergisi, 9(1), 72-85.

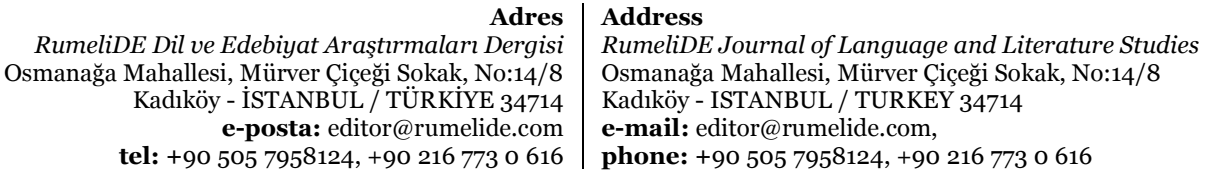


Creswell, J.W. (2018). Nitel araştırma yöntemleri: Beş yaklaşıma gore nitel araştırma ve araştırma deseni (3. Baskıdan Çeviri). Robert K. Yin (Çeviri Editörleri: M. Bütün \& S.B.Demir). Ankara: Siyasal Yayın Dağıtım.

Düzakın, E., \& Yalçınkaya, S. (2008). Web tabanlı uzaktan eğitim sistemi ve Çukurova Üniversitesi öğretim elemanlarının yatkınlıkları. Journal of the Cukurova University Institute of Social Sciences, 17(1), 225-244.

Ekmekçi, E. (2015). Distance-education in foreign language teaching: evaluations from the perspectives of freshman students. Procedia-Social and Behavioural Sciences, 176, 390-397.

Eroğlu, F. \& Kalaycı, N. (2020). Üniversitelerdeki zorunlu ortak derslerden yabancı dil dersinin uzaktan eğitim uygulamasının değerlendirilmesi. Türk Ĕ̆itim Bilimleri Dergisi, 18(1), 236-265.

Eygü, H. \& Karaman, S. (2013). Uzaktan eğitim öğrencilerinin memnuniyet algıları üzerine bir araştırma. Kırkkale Üniversitesi Sosyal Bilimler Dergisi, 3(1), 36-59.

Gökmen, Ö. F., Uysal, M., Yaşar, H., Kırksekiz, A., Güvendi, G. M., \& Horzum, M. B. (2017). Türkiye’de 2005-2014 yılları arasında yayınlanan uzaktan eğitim tezlerindeki yöntemsel eğilimler: Bir içerik analizi. Ĕ̆itim ve Bilim, 42(189).

Gürer, M. D., Tekinarslan, E., \& Yavuzalp, N. (2016). Çevrimiçi ders veren öğretim elemanlarının uzaktan eğitim hakkındaki görüşleri. Turkish Online Journal of Qualitative Inquiry, 7(1).

İbicioğlu, H., \& Antalyalı, Ö. L. (2005). Uzaktan eğitimin başarısında imkân algı motivasyon ve etkileşim faktörlerinin etkileri: karşılaştırmalı bir uygulama. Çukurova Üniversitesi Sosyal Bilimler Enstitüsü Dergisi, 14(2), 325-338.

Kandemïr, O. (2014). Türkiye'de yükseköğretim düzeyinde uzaktan eğitim uygulamaları: eğitimde fırsat eşitliği ve ekonomik kalkınma. Electronic Turkish Studies, 9(5), 1155-1176.

Keegan, D. (1996). Foundations of distance education (3rd ed.). London: Routledge.

Kör, H., Çataloğlu, E., Erbay, H. (2013).Uzaktan ve örgün eğitimin öğrenci başarısı üzerine etkisinin araştırılması. Gaziantep Üniversitesi Sosyal Bilimler Dergisi, 12(2), 267-279

Larreamendy-Joerns, J., \& Leinhardt, G. (2006). Going the distance with online education. Review of Educational Research, 76(4), 567-605.

Merriam, S. B. (2018). Nitel araştırma: Desen ve uygulama için bir rehber (3. Baskıdan Çeviri, Çeviri Editörü: S. Turan). Ankara: Nobel Yayın Dağıtım.

O’Malley, J., \& McCraw, H. (1999). Students perceptions of distance learning, online learning and the traditional classroom. Online Journal of Distance Learning Administration, 2(4), 1-9.

Ozan, Ö. \& Göçmenler, H. (2018). Türkçenin yabancı dil olarak uzaktan farklılaştırılmış öğretimi projesi. Uludağ Üniversitesi Eğitim Fakültesi Dergisi, 31(Özel Say1), 129-134.

Öztürk, A. (2006). Bilgisayar destekli öğretimde geribildirim türü ve zamanlamasının öğrenci başarısı ve öğrenmede kahıcllk üzerindeki etkisi (Yüksek lisans tezi). Yükseköğretim Kurulu Ulusal Tez Merkezi'nden edinilmiştir. (Tez No: 215406)

Papalas, M. (2013). New Orientations for French Language Learning: Is Synchronous Distance Education a Viable Solution? The French Review, 87(1), 99-111.

Patton, M.Q. (2014). Nitel araştırma ve değerlendirme yöntemleri (3. Baskıdan Çeviri, Çeviri Editörleri: M. Bütün \& S.B. Demir.). Ankara: Pegem Akademi.

Pilancı, H. (2009). Uzaktan Türkçe öğrenen yabancıların Türkçeyi iletişim aracı olarak kullanabilme yeterlikleri. Dil ve Dilbilimi Çalışmaları Dergisi, 5(2), 49-61.

Saldana, J. (2019). Nitel Araştırmacılar İçin Kodlama El Kitabı (3. Baskıdan çeviri, Çeviri editörleri: A. Tüfek Ekici ve S. N. Şad). Ankara: Pegem Akademi.

Semradova, I., \& Hubackova, S. (2016). Teacher responsibility in distance education. Procedia-Social and Behavioral Sciences, 217, 544-550.

\begin{tabular}{|c|c|}
\hline & \\
\hline aları $D$ & d Literatur \\
\hline $\mathrm{Mal}$ & Mahallesi, Mürver Çiçeği Sokak, No:14/8 \\
\hline Kadıköy & STANBUL / TURKEY 34714 \\
\hline $\begin{array}{r}\text { e-posta: edito } \\
\text { tel: }+905057958124,+\end{array}$ & $\begin{array}{l}\text { editor@rumelide.com, } \\
\text { +90 505 7958124, +90 } 216773 \text { o } 616\end{array}$ \\
\hline
\end{tabular}


Silverman, D. (2018). Nitel verileri yorumlama (5. Baskıdan çeviri, Çeviri editörü: E. Dinç). Ankara. Pegem Akademi.

Şahin, M. C., \& Tekdal, M. (2005). İnternet tabanlı uzaktan eğitimin etkililiği: Bir meta-analiz çalışması. Akademik Bilişim Konferansı, 2-4 Şubat 2005, Gaziantep, 02-04.

Şen, B., Atasoy, F., \& Aydın, N. (2010). Düşük maliyetli web tabanlı uzaktan eğitim sistemi uygulaması. Akademik Bilişim Konferansı, 10-12 Şubat 2010, Muğla, 10-12.

Şen, Ü. (2016). Yabancı Dil Olarak Türkçe Öğretiminde Uzaktan Eğitim Programları. Journal of Kirsehir Education Faculty, 17(2), 411-428.

Ulmer, L. W., Watson, L. W., \& Derby, D. (2007). Perceptions of higher education faculty members on the value of distance education. Quarterly Review of Distance Education, 8(1), 59-70.

URL 1. https://www.telc.net/fileadmin/user_upload/Publikationen/Diller_iain_Avrupa_Ortak _oneriler_AEeraevesi.pdf

Yıldırım, A. \& Şimşek, H. (2018). Sosyal bilimlerde nitel araştırma yöntemleri (11.baskı). Ankara: Seçkin Yayıncılık.

Yiğit, T., Aruğaslan, E., Özaydın, B., Tonguç, G., \& Özkanan, A. (2012). Geleneksel eğitim ve uzaktan eğitimde öğrenen başarılarının karşılaştırılması: temel bilgi teknolojileri kullanımı dersi örneği. Eğitim Teknolojileri Araştırmaları Dergisi (ET-AD), 3(3), 1539-1542.

Yin, R. (2014). Case study research: Design and methods (5th Ed.). London: Sage.

Zhang, X. (2018). Mitigating suburban English writing teachers' constrained professional development through distance education: One case study. The International Review of Research in Open and Distributed Learning, 19(5), 239-254.

Zhao, Y., Lei, J., Yan, B., Lai, C., \& Tan, H. S. (2005). What makes the difference? A practical analysis of research on the effectiveness of distance education. Teachers College Record, 107(8), 1-83. 


\section{Ek1. Yabancı dil olarak Türkçe öğretiminde uzaktan eğitimle ilgili görüşme formları}

Öncelikle katılımınız için çok teşekkür ederim. Çalışmada uygulayacağımız etik hassasiyetle ilgili size bilgi vermek istiyorum. Bu görüşme kapsamında sizden alınan kişisel bilgiler kesinlikle paylaşılmayacaktır. Çalışmanın raporlaştırması esnasında görüşlerinize katılımcı 1-2'nin görüşleri şeklinde yer verilecektir.

Bu araştırmayı yabancı dil olarak Türkçe öğretiminde uzaktan eğitimle yapılan dersleri öğretici ve öğrenci merkezli incelemek amacıyla düzenledim. Görüşme esnasında kendi deneyim ve tecrübelerinizden hareketle içtenlikle cevap vermeniz çalışma için büyük önem arz etmektedir.

Hazırsanız sorularımıza başlayabiliriz.

\section{Öğretim elemanları}

\section{Katılımcıla ilgili bilgiler}

1. Yaş:

2. Cinsiyet:

3. Uzaktan eğitimle ders yapma geçmişi:

4. Uzaktan eğitim konusunda kullanılan programlar:

5. Türkçe öğretimiyle ilgili daha önce kullanılan uygulamalar \araçlar:

\section{Sorular}

1. Bir eğitici olarak uzaktan eğitimle Türkçe öğretimine yönelik görüşleriniz nasıldır? Açıklayınız.

2. Bir eğitici olarak uzaktan eğitimle Türkçe öğretimi yapmak konusunda kendinizden nasıl bir performans bekliyorsunuz? Ayrıntılı bir şekilde açıklayabilir misiniz?

3. Uzaktan eğitimle Türkçe öğretimi sonucunda öğrencilerin hangi kazanımlara ulaşacağını düşünüyorsunuz?

4. Uzaktan eğitimle Türkçe öğretim sonucunda öğrencilerin hangi kazanımlarda eksiklik yaşayacağını düşünüyorsunuz?

5. Uzaktan eğitimle Türkçe öğretimindeki derslerin dil becerileri bazında nasıl etkileri olduğunu düşünüyorsunuz?

Katkılarınız için çok teşekkür ederim eklemek istediğiniz herhangi bir şey var mı?

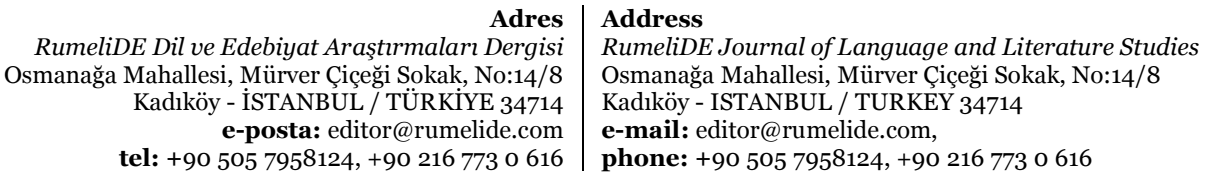

tel: +90 505 7958124, +90 2167730616 


\section{Öğrenciler}

\section{Katılımc1yla ilgili bilgiler}

Yaş:

Cinsiyet:

Uyruk

Uzaktan eğitimle ders yapma geçmişi:

Daha önce kullanılan öğretim teknolojileri:

\section{Sorular}

1. Uzaktan eğitimle Türkçe öğretimi ders süreciyle ilgili genel olarak düşünceleriniz nelerdir?

2. Uzaktan eğitimle Türkçe öğretimi derslerinizin nasıl yürütüldüğüyle ilgili bilgi verir misiniz? Dersleriniz nasıl geçti?

3. Uzaktan eğitimle Türkçe öğretimindeki derslerin dil becerileri bazında nasıl etkileri olduğunu düşünüyorsunuz?

4. Uzaktan eğitimle Türkçe öğretimi esnasında eğiticilerinizle olan iletişimi değerlendirir misiniz? Lütfen örneklerle değerlendirme yapın.

5. Uzaktan eğitimle Türkçe öğretiminde kazandığınız deneyimler çerçevesinde bir değerlendirme yapar mısınız?

\footnotetext{
Adres $\mid$ Address

RumeliDE Dil ve Edebiyat Araşttrmalar Dergisi Osmanağa Mahallesi, Mürver Çiçeği Sokak, No:14/8 Kadıköy - ISTANBUL / TÜRKIYE 34714 e-posta: editor@rumelide.com

RumeliDE Journal of Language and Literature Studies Osmanağa Mahallesi, Mürver Çiçeği Sokak, No:14/8

Kadıköy - ISTANBUL / TURKEY 34714

e-mail: editor@rumelide.com

tel: +90 505 7958124, +90 2167730616 phone: +90 505 7958124, +90 2167730616
} 
Ek 2. Yabancı dil olarak Türkçe öğretiminde uzaktan eğitim ortamına yönelik yarı-yapılandırılmış gözlem formu

\begin{tabular}{|c|c|c|}
\hline & & NOTLAR \\
\hline \multirow{2}{*}{$\begin{array}{l}\text { İletişim } \\
\text { becerileri } \\
\text { (hoca- } \\
\text { ögrrenci) }\end{array}$} & $\begin{array}{l}\text { Kendini ifade } \\
\text { etme durumu }\end{array}$ & \\
\hline & Konuşma üslubu & \\
\hline \multirow{3}{*}{$\begin{array}{l}\text { Uzaktan sinıf } \\
\text { yönetimi } \\
\text { (hoca) }\end{array}$} & $\begin{array}{l}\text { Ders ortaminda } \\
\text { atmosfer }\end{array}$ & \\
\hline & Zaman yönetimi & \\
\hline & $\begin{array}{l}\text { Disiplin ve } \\
\text { kurallar }\end{array}$ & \\
\hline \multirow{4}{*}{$\begin{array}{l}\text { Ölçme } \\
\text { değerlendirme } \\
\text { faaliyetleri } \\
\text { (hoca ve } \\
\text { öğrenci) }\end{array}$} & $\begin{array}{l}\text { Açılk uçlu veya } \\
\text { kısa cevaplı } \\
\text { sorular sorma }\end{array}$ & \\
\hline & $\begin{array}{l}\text { Kisa veya uzun } \\
\text { yanitlar verme }\end{array}$ & \\
\hline & $\begin{array}{l}\text { Öğrenciler } \\
\text { sorular } \\
\text { karşısındaki } \\
\text { davranışları }\end{array}$ & \\
\hline & $\begin{array}{l}\text { Hocanın } \\
\text { cevaplara verdiği } \\
\text { dönütler }\end{array}$ & \\
\hline \multirow[t]{3}{*}{$\begin{array}{l}\text { Teknolojik } \\
\text { yeterlikler } \\
\text { (hoca ve } \\
\text { ögrrenci) }\end{array}$} & $\begin{array}{l}\text { Hocanın uzaktan } \\
\text { eğitim } \\
\text { programını } \\
\text { kullanma } \\
\text { durumu }\end{array}$ & \\
\hline & $\begin{array}{l}\text { Öğrencinin } \\
\text { uzaktan eğitim } \\
\text { programını } \\
\text { kullanma } \\
\text { durumu }\end{array}$ & \\
\hline & $\begin{array}{l}\text { Hocanın } \\
\text { kullandığı } \\
\text { materyaller }\end{array}$ & \\
\hline
\end{tabular}

\section{Serbest Notlar:}

Address

RumeliDE Journal of Language and Literature Studies

Osmană̆a Mahallesi, Mürver Çiçeği Sokak, No:14/8

Kadıköy - ISTANBUL / TURKEY 34714

e-mail: editor@rumelide.com

phone: +90 505 7958124, +90 2167730616 